SHELFLIFE OF WHOLE FRESH LAKE MALAWI TILAPIA (Oreochromis species - Chambo) STORED IN ICE

\title{
Kapute $\mathrm{F}^{1}$, Likongwe $\mathrm{J}^{2}$, Kang'ombe $\mathrm{J}^{3}$ and $\mathrm{C}$ Kiiyukia ${ }^{4}$
}

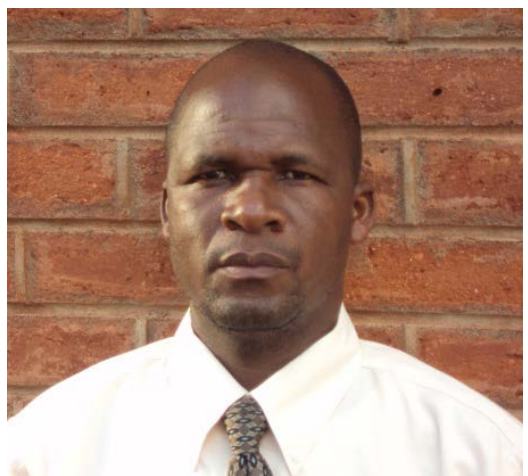

Fanuel Kapute

*Corresponding author email: fkapute@gmail.com

${ }^{1}$ Senior Lecturer and PhD (Fish Quality Management) Candidate, Department of Aquaculture and Fisheries Science, Bunda College of Agriculture (University of Malawi), P.O. Box 219, Lilongwe, Malawi.

${ }^{2}$ Associate Professor in Aquaculture and Fisheries, Department of Aquaculture and Fisheries Science, Bunda College of Agriculture (University of Malawi), P.O. Box 219, Lilongwe, Malawi.

${ }^{3}$ Associate Professor in Aquaculture Nutrition, Department of Aquaculture and Fisheries Science, Bunda College of Agriculture (University of Malawi), P.O. Box 219, Lilongwe, Malawi.

${ }^{4}$ Senior Lecturer in Medical Microbiology, Institute of Tropical Medicine and Infectious Diseases, Jomo Kenyatta University of Agriculture and Technology, P.O. Box 62000 - 00200, Nairobi, Kenya. 


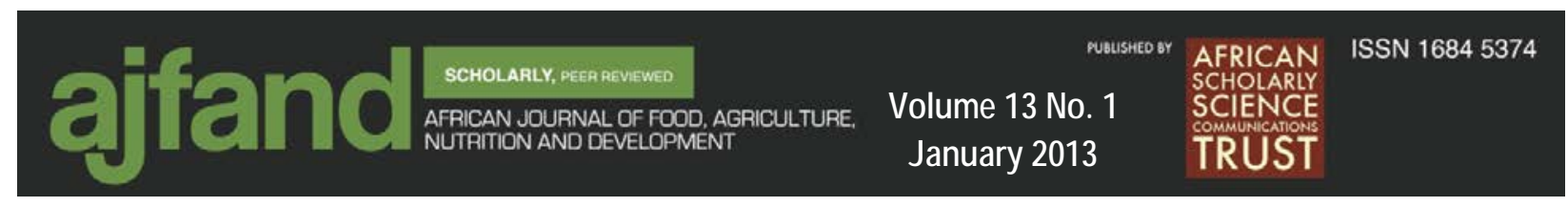

ABSTRACT

Lake Malawi Tilapia (chambo) fish species is widely consumed and forms the most important commercial fishery in Lake Malawi. However, as a highly perishable commodity, knowledge regarding how long fresh fish would remain in acceptable and safe condition in storage is indispensable for consumers and processors. Presently, no such information exists for the Lake Malawi Tilapia in Malawi. A study was therefore conducted to estimate shelflife of whole fresh Lake Malawi Tilapia stored in ice (0 ${ }^{\circ} \mathrm{C}$ ) for 21 days. Sensory, microbiological and $\mathrm{pH}$ analyses were conducted to describe changes in quality and freshness of the fish with storage time in ice. Shelflife of the fish was estimated between 16 and 18 days. A strong linear correlation $\left(\mathrm{R}^{2}=0.95\right)$ was observed between sensory demerit scores and storage time in ice. Total bacteria viable counts and $\mathrm{pH}$ at the time of sensory rejection of the fish were $1.6 \times 10^{7} \mathrm{cfu} / \mathrm{g} / \mathrm{cm}^{2}$ and 5.84 respectively. Pseudomonas and Micrococcus bacteria were found in relatively high numbers throughout the storage period. The study demonstrated that like other tropical fish, Lake Malawi Tilapia has a relatively longer shelflife. The long storage life in ice of Lake Malawi Tilapia is advantageous to most small scale fresh fish sellers and processors especially from rural areas in Malawi who solely depend on ice as a sole and affordable way of preserving fresh fish.

Key words: Shelflife, Tilapia, ice storage 


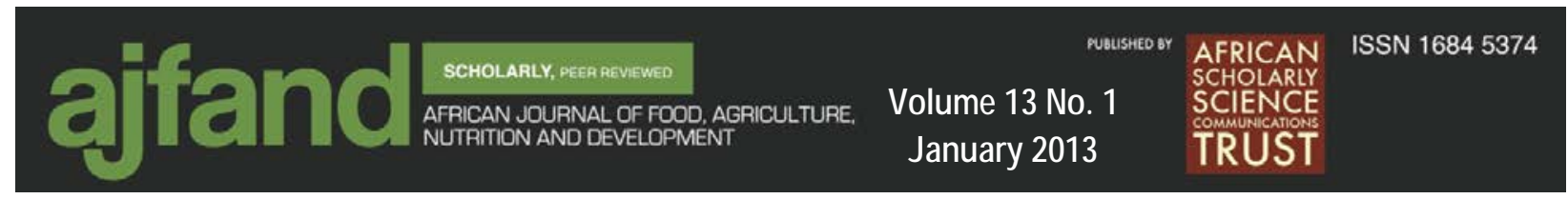

\section{INTRODUCTION}

Issues regarding quality and safety of fish and fish products are gaining global attention due to the fact that fish is a highly perishable commodity. After death, a series of complex biochemical processes set in culminating into spoilage of fresh fish over time [1]. Time and temperature are probably the most critical factors that require particular attention to minimize fish spoilage [2].

Several studies regarding shelflife of freshwater tropical fish including tilapias are available [3]. However, no such work has been reported for the Lake Malawi Tilapia (locally known as chambo) - an endemic species to Lake Malawi. Shelflife of fish is also influenced by the geographical location [1]. Although much work on the shelflife of tilapia exists, the fact that the chambo is endemic to Lake Malawi justifies the need for a similar but independent and exclusive study.

Lake Malawi Tilapia forms an important commercial fishery and it is probably the most widely accepted and highly valued harvested commercial fish species in Malawi [4]. The majority of the catches by the artisanal fishermen come from Lake Malawi, especially the shallow and productive south-eastern arm of the lake [5]. A considerable catch is also obtained from Lake Malombe where the fishery has nearly collapsed due to uncontrolled fishing [6].

Most of the fish catch is preserved in ice packed in bamboo baskets and transported in open vehicles to various markets in Malawi. However, spoilage in fresh fish progresses even when stored in ice resulting into gradual loss of freshness and quality [1]. Activity of microbes and enzymes has been pin-pointed for causing spoilage of fresh fish in ice [7]. The fact that the chambo is transported to distant places from the lake underscores the need for estimating the duration it would remain in safe and acceptable condition. Such information is greatly required by consumers and processors.

The study, therefore, was carried out to investigate the shelflife for whole fresh Lake Malawi Tilapia (Oreochromis species), as well as the spoilage pattern of the fish stored in ice.

\section{MATERIALS AND METHODS}

\section{Fresh fish sample collection}

Sixty whole fresh chambo fish were collected from fish sellers early in the morning at the southeast arm of Lake Malawi less than an hour after catch. The fish were immediately and carefully put in cooler boxes loaded with fresh block ice. The fish were not washed with water to avoid influencing the sensory evaluation process [8]. Fish of approximately similar sizes (average total length and weight of $25 \mathrm{~cm}$ and $240 \mathrm{~g}$ respectively) were deliberately selected during collection to reduce variability factors that would cause bias in the shelflife estimation process [9]. Size of fish is one of the intrinsic factors that affect the rate of spoilage in fresh fish stored in ice [10]. Water from the melted ice in the cooler box was decanted and fresh ice blocks added 


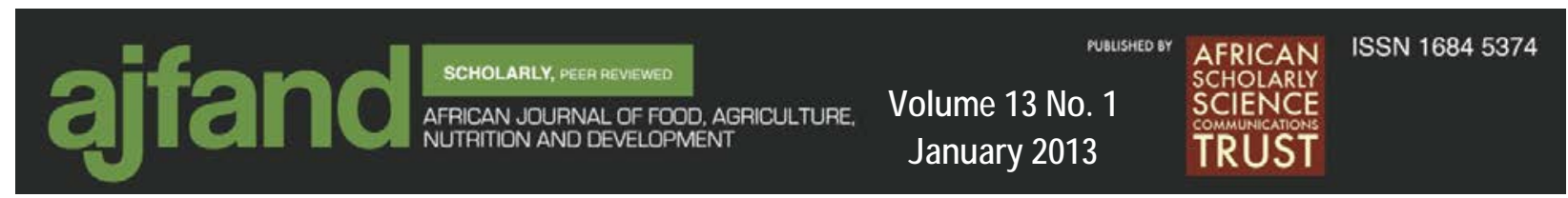

every one to two days during the entire period of fish sample analysis. Enough block ice (about $10 \mathrm{~kg}$ ) was added at each interval making sure that the fish were completely covered with ice in the cooler box.

\section{Sensory evaluation}

A pre-trained sensory evaluation panel consisting six members described daily changes in freshness and quality of whole fresh chambo during storage in ice for 21 days in the laboratory using the developed quality index method (QIM) Scheme (Table 1). The sensory evaluation panel was trained in determining changes in sensory quality and freshness attributes in fresh fish namely; appearance of the skin, gills, eye cornea and scales; mucus on the gills, smell of the gills and finally, the texture of the backside and the belly. The Quality Index Method (QIM) Scheme was developed following an earlier outlined procedure [11]. The demerit scores in QIM ranged between 0 and 3, where zero represented very fresh fish (at catch) and increasingly larger totals as the fish freshness deteriorated during storage. Fish were rejected as not fit for human consumption when the overall sensory quality index (QI) with a maximum value of 16 was obtained after highest scores for each freshness and quality descriptor were added together (Table 1).

\section{Microbiological analysis}

Microbiological analysis in this study followed a previously used procedure [12]. Samples for aerobic psychrotrophic bacterial counts were obtained on the external surfaces (skin), flesh (tissue/muscle), gills and enterobacteriaceae counts from kidneys and intestines.

\section{Viable aerobic bacterial count Skin surface}

To determine bacteria on the skin surface of the fish, a sterilised rectangular wire swab guide measuring $5 \mathrm{~cm}$ by $2 \mathrm{~cm}$ was placed on the lateral surface of the fish sample. A sterile cotton wool swab dipped in $0.10 \%$ sterile peptone water was rubbed over the surface of the fish on the area covered by the wire swab guide. The swab was then immediately placed in a sterile sample vial containing $100 \mathrm{mls}$ of $0.10 \%(\mathrm{w} / \mathrm{v})$ peptone water. The vial was vigorously shaken for 10 minutes and allowed to stand for 20 minutes. Six fold serial dilution of the bacterial suspension in peptone water was prepared in duplicate and viable aerobic bacterial counts were enumerated in standard plate count agar after incubation at $37^{\circ} \mathrm{C}$ for 48 hours. Results were reported in $\log \mathrm{cfu} / \mathrm{cm}^{2}$ [12].

\section{Intestines, gills, kidney and tissue (muscle/flesh)}

One gram of the fish sample from a chosen part was dissected, blended and mixed properly in a mortar then aseptically transferred to a sample vial containing $9 \mathrm{mls}$ of $0.1 \%$ sterile peptone water. The vial was closed and shaken thoroughly for 10 minutes, then allowed to stand for 20 minutes, after which a 6 fold serial dilution was carried out in triplicates. Viable aerobic bacterial counts were enumerated in standard plate count agar after incubation at $37^{\circ} \mathrm{C}$ for 48 hours. Results were reported in log cfu/g [12]. 


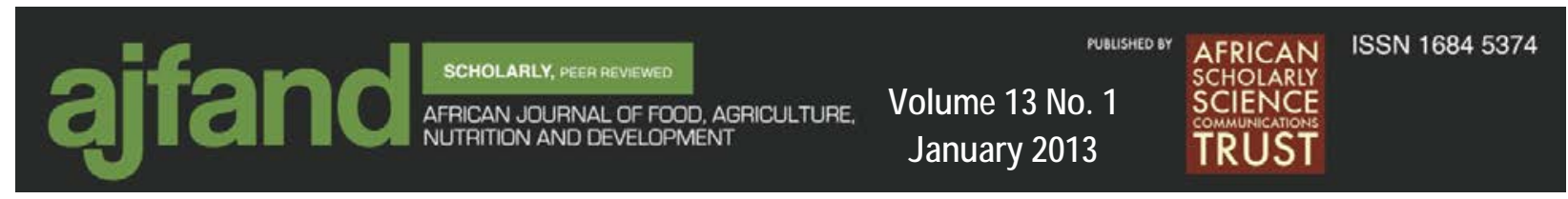

\section{Identification of bacteria}

Morphological characteristics of the various bacterial isolates were noted in the agar plates, and microscopy. After staining reactions and several biochemical tests, individual microbial species were identified. Representative isolates were re-plated on various selective media to observe their specific colonial attributes so as to further separate the aerobic bacterial species [12].

\section{Physical analysis \\ Determination of $\mathrm{pH}$}

The $\mathrm{pH}$ of the fish was determined by removing part of the flesh (muscle) and weighed $10 \mathrm{~g}$. The sample was then homogenized in $50 \mathrm{ml}$ of distilled water and centrifuged using a Yamato Mag-Mixer Model MH 800 (Yamato Scientific Company Limited, Japan). The mixture was filtered using Whatman filter paper No.1. A pH meter (Model No. WTW-8120, West Germany) electrode was then inserted into the homogenate to measure the $\mathrm{pH}$ at ambient temperature after calibration using standard buffers of $\mathrm{pH} 7$ and 4 at $25{ }^{\circ} \mathrm{C}$ [12].

\section{STATISTICAL DATA ANALYSIS}

Data were analysed using the statistical software SPSS 15.0 for Windows 2007. A linear regression analysis of sensory changes against storage time in ice was performed on the sensory quality data using Microsoft Excel 2010 [13]. Mean differences between quality indicators and storage time of the fish in ice were compared using analysis of variance (ANOVA). Means standard deviation $( \pm S D)$ were reported at 5\% level of significance. Pearson correlations between sensory, microbiological and $\mathrm{pH}$ parameters were also performed. Multivariate comparison of different sensory attributes and samples were performed using Principal Component Analysis (PCA) for the mean sensory attribute values with full cross validation [14]. PCA were computed using The Unscrambler ${ }^{\circledR}$ X Version 10.1 Statistical Software (C) 2009-2011 (CAMO, Norway).

\section{RESULTS}

\section{Sensory evaluation}

Highest quality index (QI) demerit scores were recorded at day 16 extending up to day 18 suggesting that the fish were rejected by the sensory panel after 16 days from day of catch (Figure 1). QI value for day 16 was 15.5 and 15.7 for day 19. 

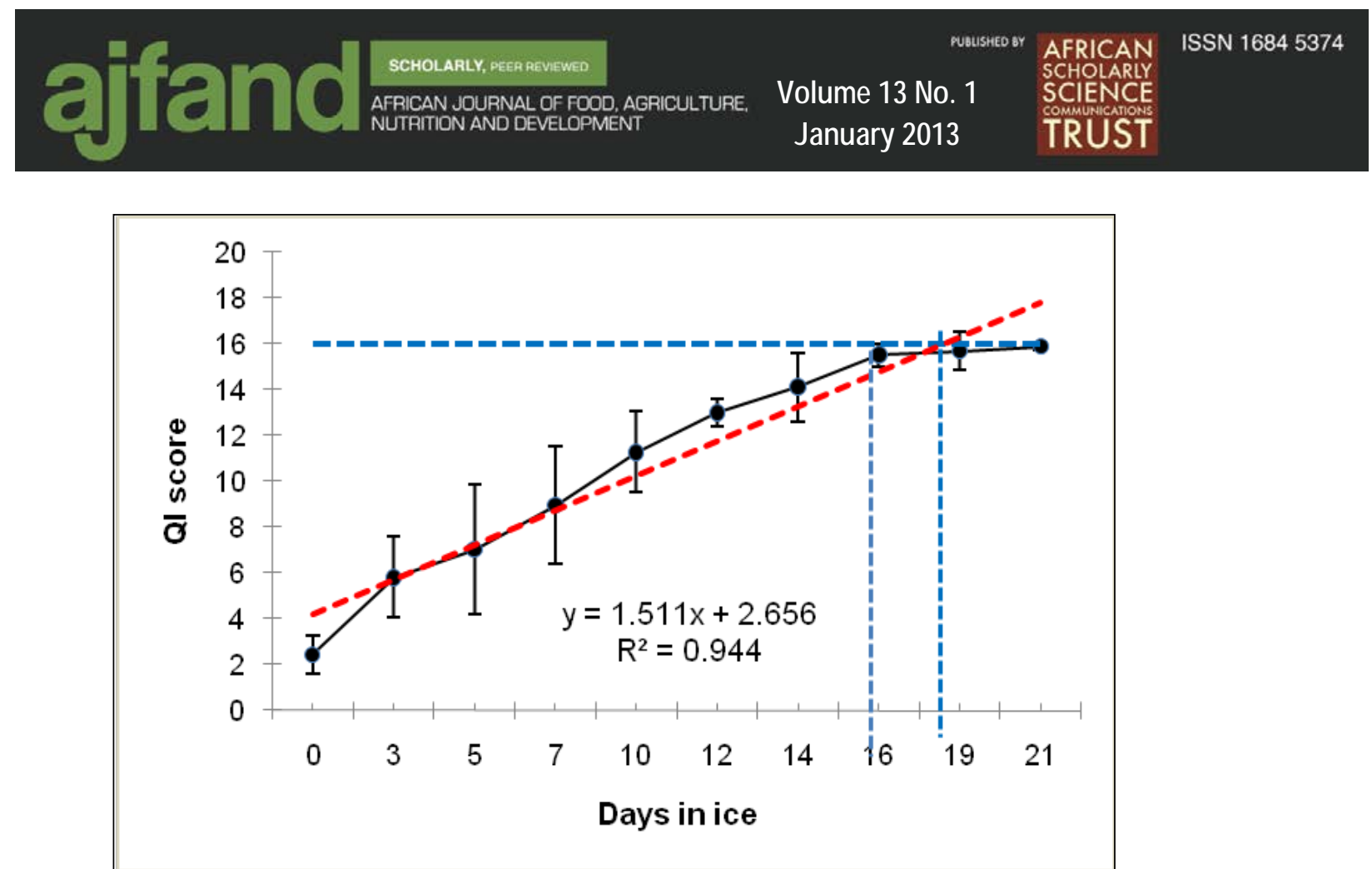

Figure 1: Quality Index (QI) of Lake Malawi tilapia (chambo) fish stored in ice for 21 days

This suggests that whole fresh chambo stored in ice can remain in acceptable condition for consumption between day 16 and day 18. A strong $(\mathrm{P}<0.01)$ linear correlation between sensory scores and days of storage in ice of the fish was observed (Table 2).

Nearly all sensory quality attributes increased proportionally with storage time in ice and stagnated after sensory rejection (Figure 2) indicating that perception of the sensory panel regarding freshness and quality of the fish did not change for any better after rejection. 


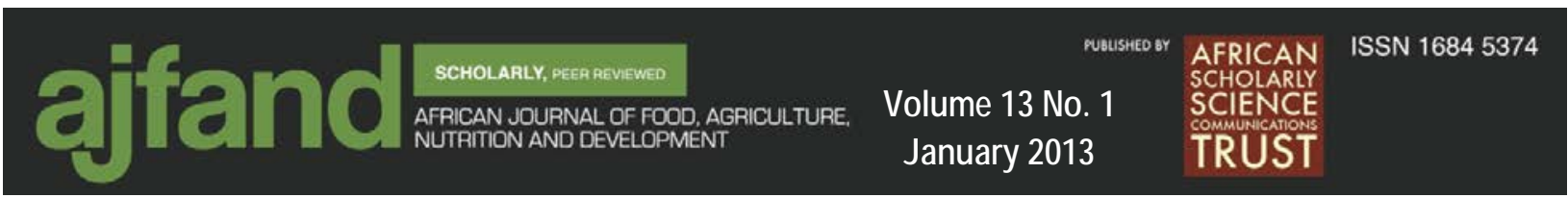

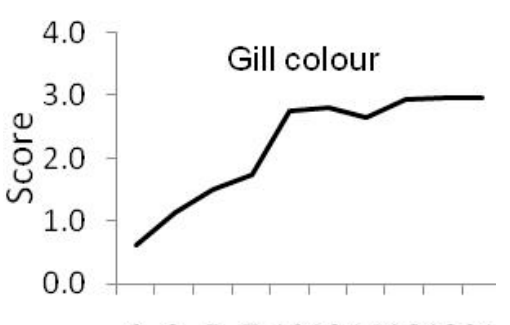

$0 \quad 3 \quad 57101214161921$

Days in ice

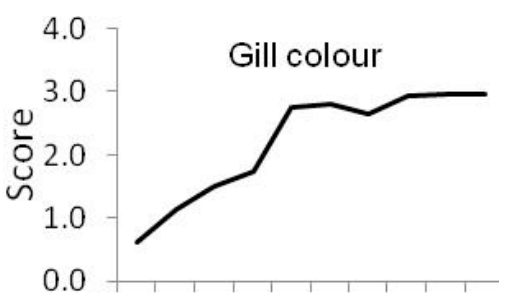

0357101214161921

Days in ice

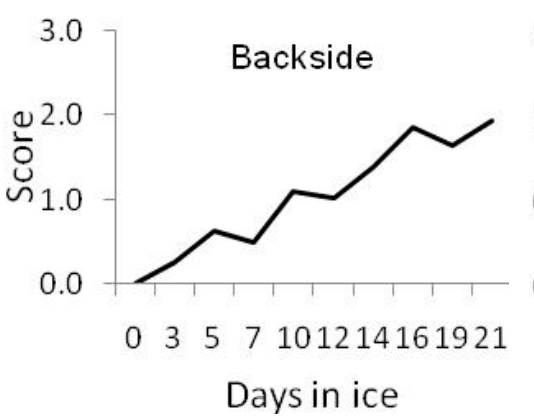

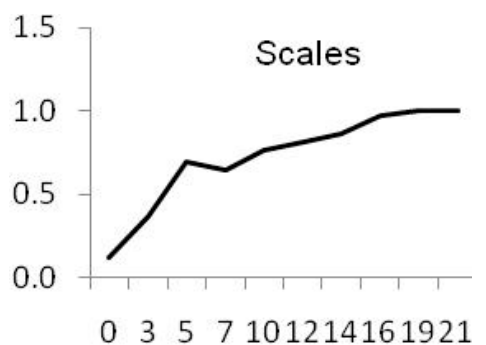

Days in ice

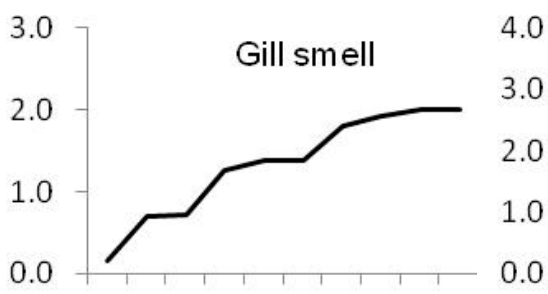

$0 \quad 3 \quad 57101214161921$

Days in ice

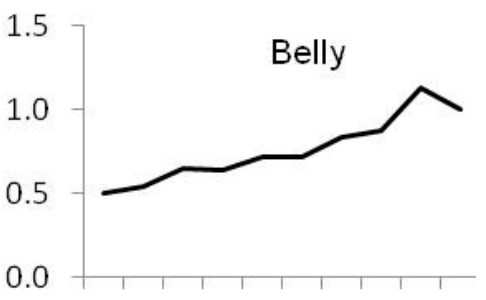

$0 \quad 357101214161921$

Days in ice

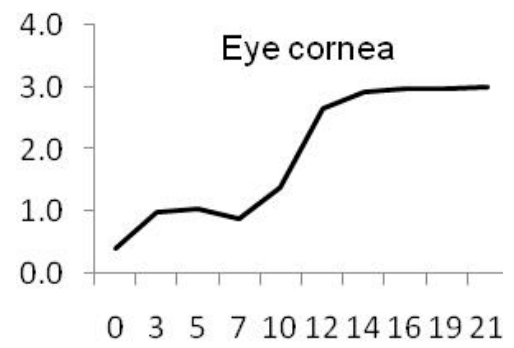

Days in ice

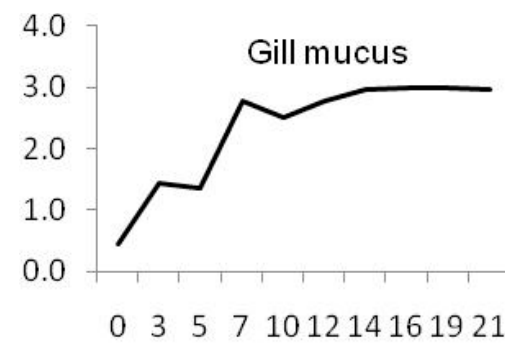

Days in ice

Figure 2: Average scores for quality attributes assessed with QIM scheme for whole fresh Lake Malawi Tilapia (chambo) fish against storage days in ice

There were highly significant $(\mathrm{P}<0.05)$ differences between storage time of the fish in ice against freshness score (QI). Appearance of the gills, eye cornea and mucus were probably the major sensory attributes that influenced the determination of freshness and quality of the fish during storage (Figure 3). 

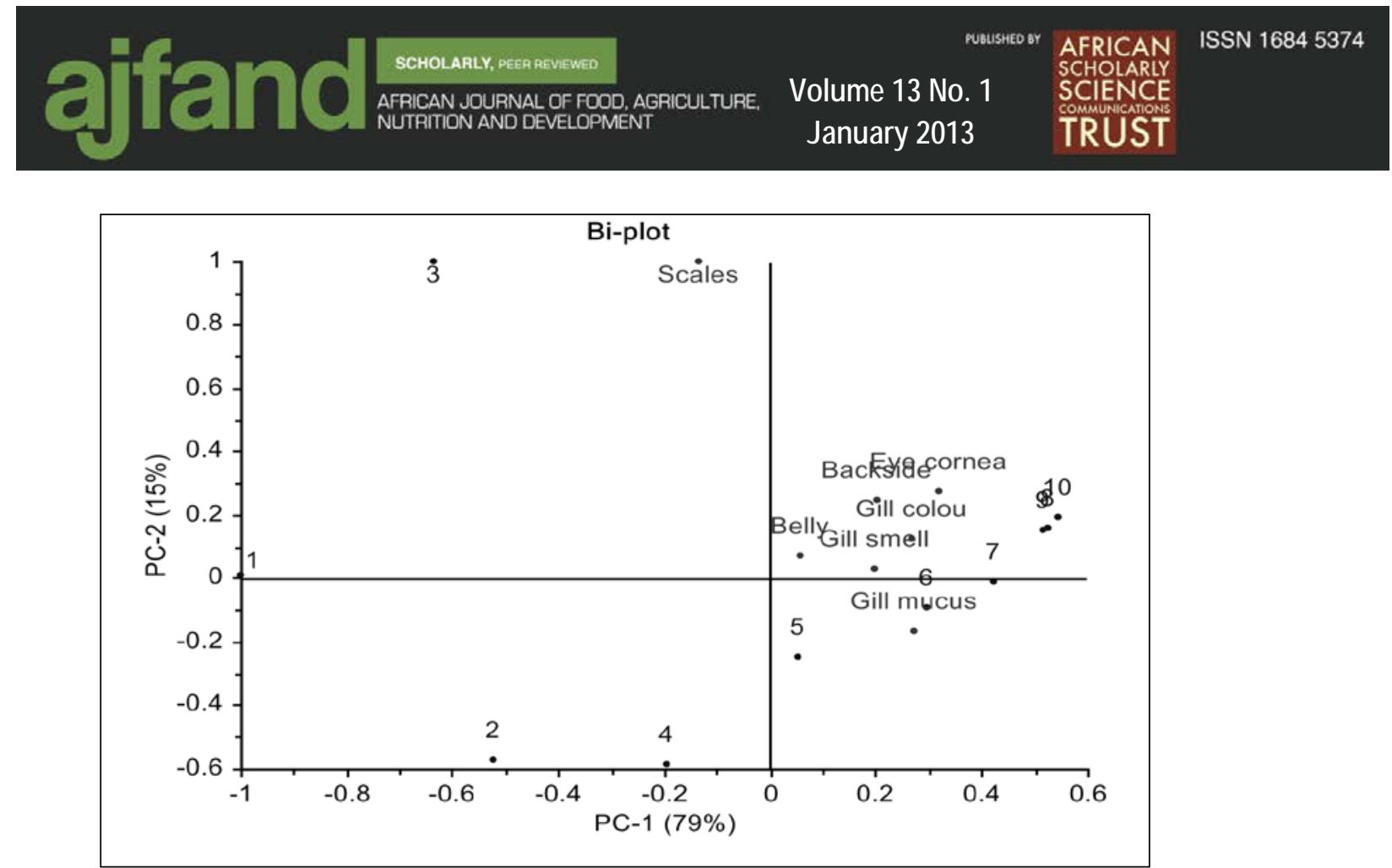

Figure 3: Principal Component Analysis (PCA) bi-plot using full cross-validation of sensory evaluation attributes: scales, eye cornea, gill mucus, gill smell, gill colour, belly appearance and backside texture for Lake Malawi Tilapia (chambo) fish stored in ice

These attributes were also highly correlated indicating their importance in sensory evaluation of fresh fish (Figure 4).

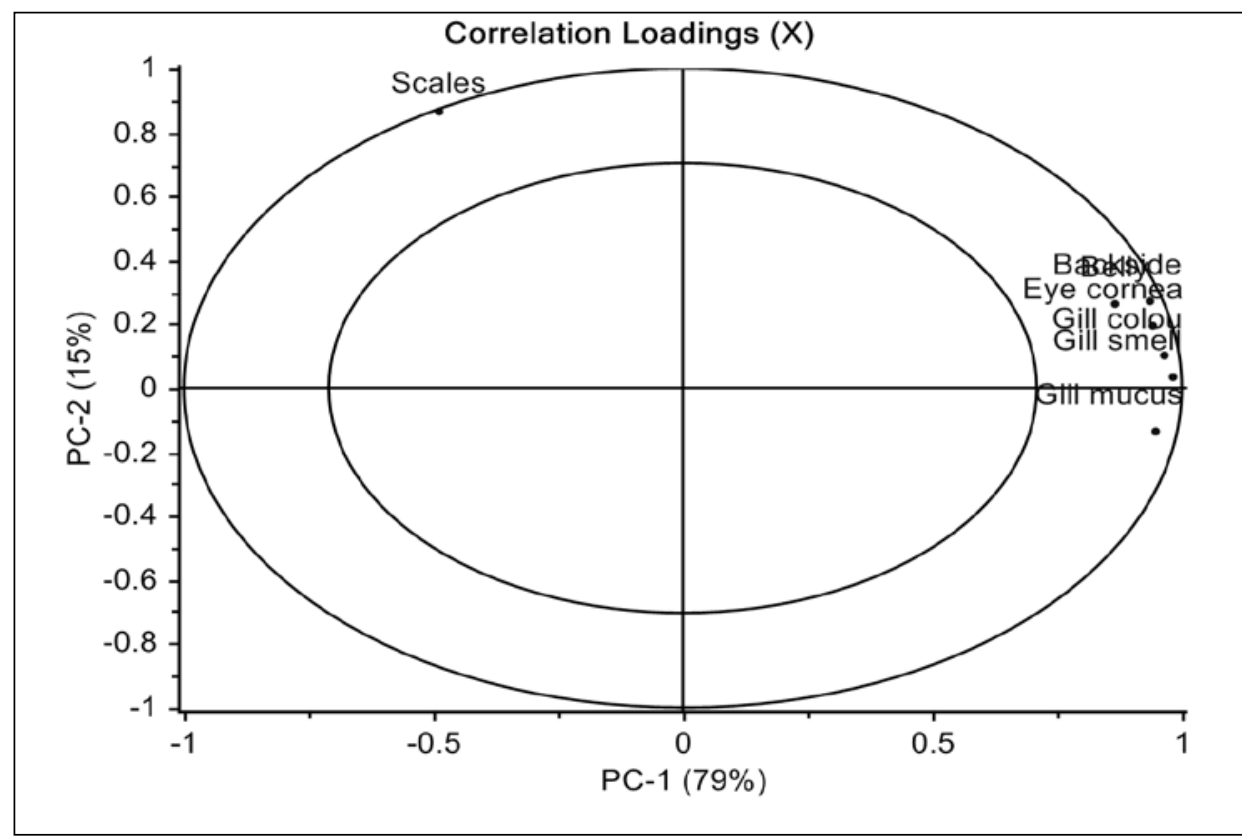

Figure 4: Correlation loadings of sensory evaluation attributes: scales, eye cornea, gill mucus, gill smell, gill colour, belly appearance and backside texture of Lake Malawi Tilapia (chambo) fish stored in ice 


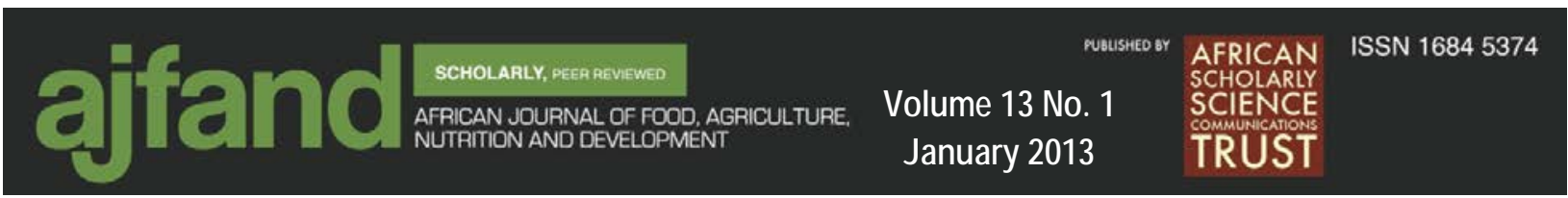

Gaping of the fillets was observed from day 12 of storage in ice and became more pronounced on day 16.

\section{Microbiological analysis}

A highest total viable count of bacteria reached at the time of sensory rejection was $1.6 \times 10^{7} \mathrm{cfu} / \mathrm{g} / \mathrm{cm}^{2}$ from an initial load of $2.9 \times 10^{4} \mathrm{cfu} / \mathrm{g} / \mathrm{cm}^{2}$ (Table 3). At the time of sensory rejection, highest and lowest bacteria populations were isolated from the intestines $\left(8.4 \times 10^{7} \mathrm{cfu} / \mathrm{g}\right)$ and skin $\left(2.8 \times 10^{4} \mathrm{cfu} / \mathrm{cm}^{2}\right)$ respectively (Table 3). The general observation was that total bacterial population increased sharply after day 12 till day 21 (Figure 5) coinciding with sensory rejection time (Figure 1).

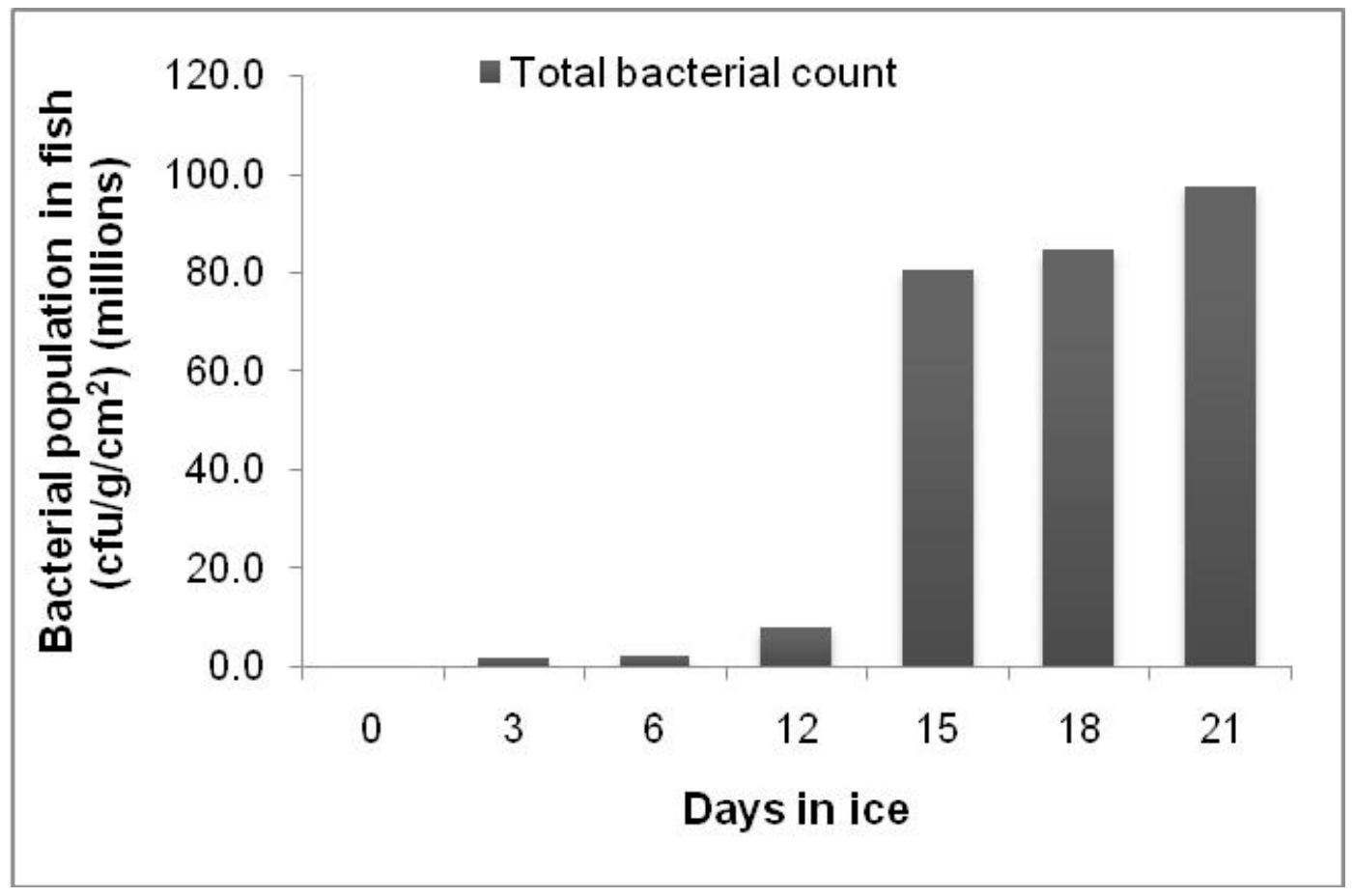

Figure 5: Total viable counts (TVC) of bacteria isolated from Lake Malawi Tilapia (chambo) fish during storage in ice for 21 days

It was also noted that constant sensory scores in figure 2 were parallel to stagnated bacterial counts (Figure 6) between day 15 and day 21. 

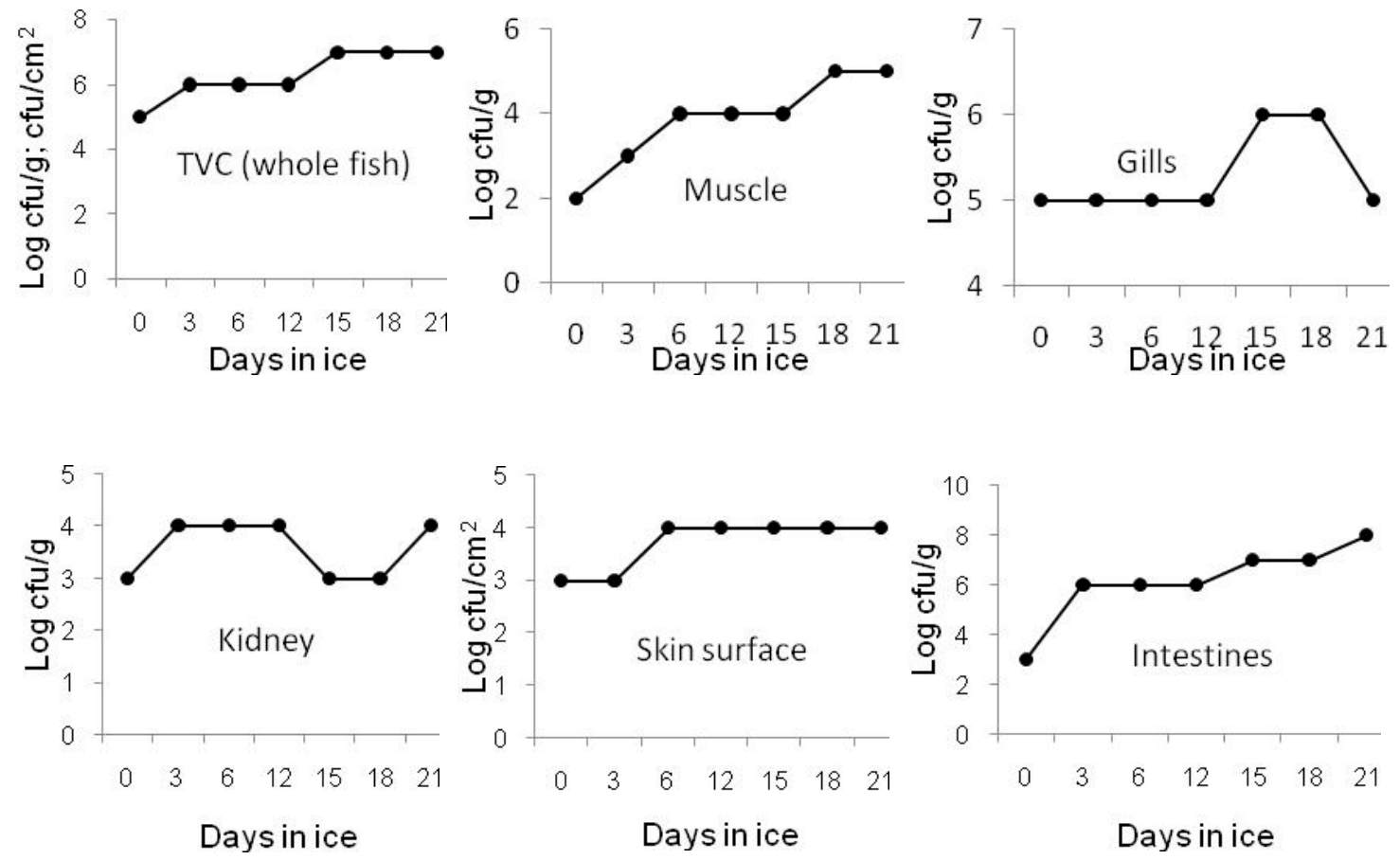

Figure 6: Populations of bacterial flora (\%) isolated from fresh Lake Malawi Tilapia (chambo) fish during storage in ice

Another interesting observation was that despite the general increase in bacterial population in the intestine of the fish, bacteria on the skin of the fish stabilized after day 6 (Figure 6). Microbiological results were significantly $(\mathrm{P}<0.05)$ positively correlated with sensory scores (Table 4) suggesting that some changes in quality of the fresh fish that influenced assessors to score the fish were activity of bacteria on the fish. Bacteria species that were common and prevalent in almost all parts of the fish samples throughout the storage period were Pseudomonas and Micrococcus with some considerable numbers of Shigella, Flavobacteria, Salmonella and Vibrio (Table 5).

\section{pH analysis}

The initial $\mathrm{pH}$ of the fish muscle recorded on day 0 was close to neutral (6.47) but decreased till day 4 (Figure 7). 

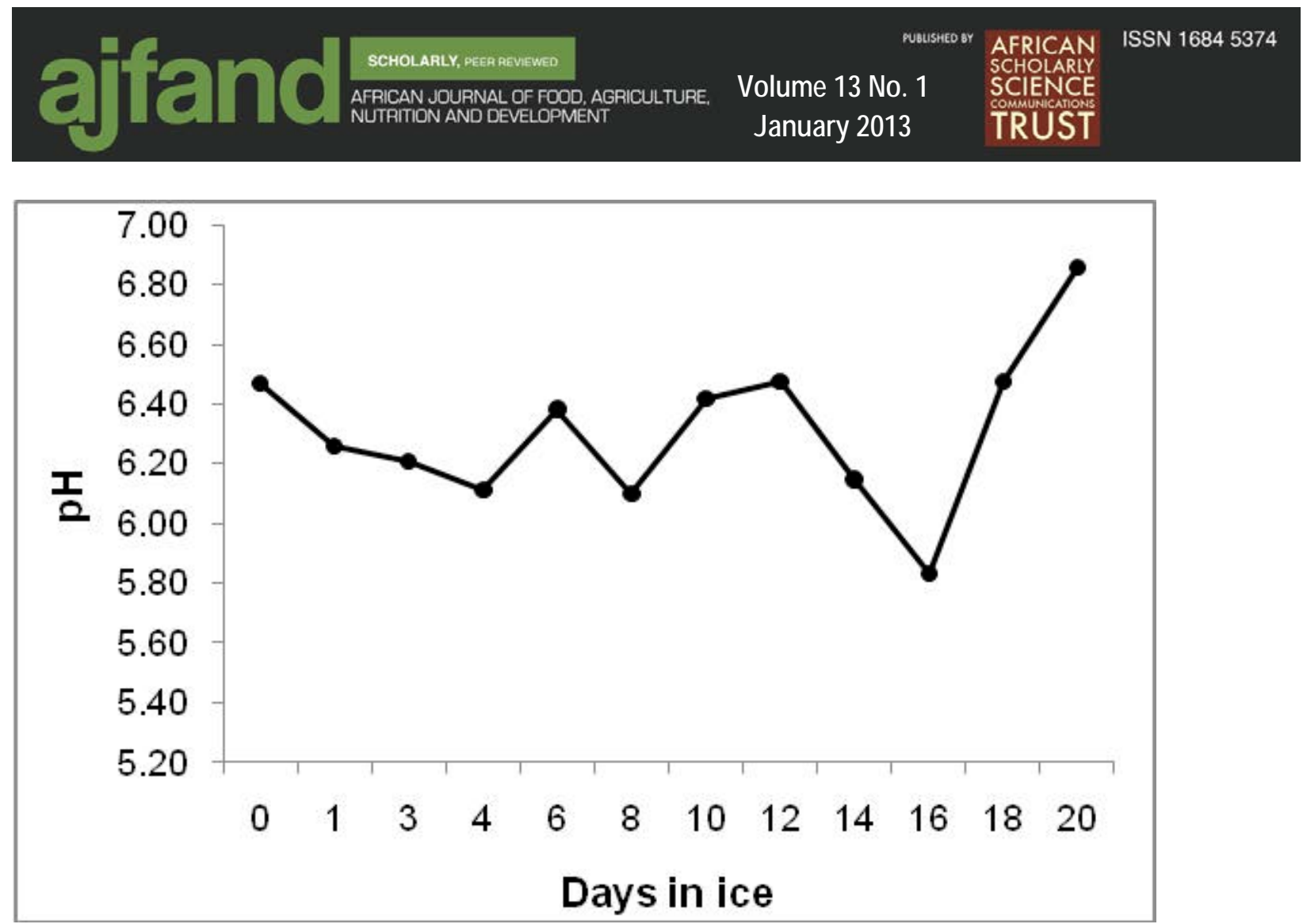

Figure 7: Changes in pH for Lake Malawi Tilapia (chambo) fish during storage in ice

The $\mathrm{pH}$ then fluctuated around 6.40 before reaching the lowest point of 5.84 on day 16 which consequently coincided with the sensory rejection time. The $\mathrm{pH}$ then rose sharply up to 6.48 and 6.86 on day 18 and 20, respectively.

\section{DISCUSSION}

Estimated shelflife of 16 days for Lake Malawi Tilapia reported in this study was in agreement with earlier studies on tilapias. Shelflife for Lake Victoria Nile perch (Lates niloticus) stored in ice has been estimated at 15 days [15] and between 13-32 days [16]. Other workers reported a 28 day [17] and 20 day [18] shelflife for Lates niloticus, respectively. Estimated shelflife for Oreochromis mossambicus was about two weeks [19]. Results reported for this study also echo earlier reports that tropical fish kept in ice exhibit a longer shelflife compared to temperate fish [1]. Bacterial counts in this study were within the range reported by previous workers on tilapia storage life. A total bacterial load of $6.2 \times 10^{4} \mathrm{cfu} / \mathrm{g}$ and $10^{6} \mathrm{cfu} / \mathrm{g}$ has, respectively, been reported for Oreochromis niloticus $[15,18]$.

This study results also demonstrated the effectiveness and importance of using ice for preserving fresh fish. In Malawi, a considerable part of the catch is lost due to lack of proper storage facilities mainly refrigerators and cold rooms. In Malawi, ice is locally available and affordable because ice making plants (machines) are found in many places. In remote areas, some traders purchase the block ice from urban areas for cooling soft drinks which are kept in plastic buckets. It is, therefore, envisaged in this study that proper use of ice would significantly reduce postharvest fresh fish losses in 


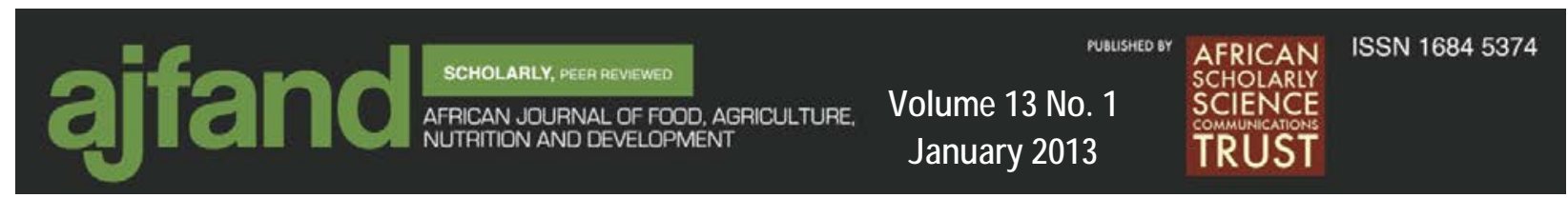

Malawi. Proper use of ice would, therefore, be helpful in places where refrigeration is not available especially rural areas of Malawi.

It was evident that use of sensory attributes such as gill colour, gill mucus and eye cornea are still the most reliable way of assessing quality and freshness of fresh fish locally. Traditionally, these are indeed the commonest freshness and quality parameters that consumers in Malawi look for before buying fresh fish on the market (pers obs). This implies that despite the challenges with the use of sensory evaluation, consistent and correct application of these attributes in sensory evaluation may still be of much benefit in fresh fish quality assessment.

The sharp increase in the bacterial population $\left(1.6 \times 10^{7} \mathrm{cfu} / \mathrm{g} / \mathrm{cm}^{2}\right)$ above acceptable levels [20] around the time of sensory rejection of the fish may also provide yet more evidence that sensory changes such as odour are directly influenced by action of microbes [1]. Since fish were kept in ice, the plausible explanation to the sharp rise in the bacterial counts after day 15 of storage could be attributed to the presence of psychrotrophic bacteria such as Pseudomonas. It is reported that bacteria often tend to pass through a lag phase of approximately one to two weeks before going into exponential growth [21]. This could probably be the best time for utilizing the fish and fish products preserved in ice by consumers to take advantage of relatively lower populations of bacteria.

Highest and lowest bacteria populations isolated from the intestines and skin, respectively, may relate to the fact that gastrointestinal tract contains huge numbers of microorganisms due to the favourable ecological niche for microbes [22]. It would be necessary therefore to encourage fish sellers to eviscerate their fish before ice storage to reduce bacterial load. Values reported in this study were however lower than earlier reported [23]. The results were nevertheless similar to other studies [2]. Lower numbers of bacteria on the skin surface could probably be a direct effect of washing of ice in which the fish were kept [24]. Other previous authors reported $10^{2}$ to $10^{4}$ and $10^{2}$ to $10^{5} \mathrm{cfu} / \mathrm{cm}^{2}$, respectively, on skin and slime [22]. Apart from the washing effect of ice, Bacteria on the fish's skin surface may only be transient rather than resident populations [1]. Probably this may also reveal the cause for the stagnated load of the bacteria. The findings are therefore central to understanding that ice is also a reliable cleaning agent which consequently lowers bacterial populations apart from its preserving effect. In general, bacterial growth increased linearly with storage time as well as with declining sensory scores suggesting why spoilage in fresh fish progresses even under cold storage [1].

Presence of more Pseudomonas and Micrococcus species of bacteria on the fish throughout the storage period is of great concern due to their pathogenicity. These bacteria have previously been isolated from intestines of Oreochromis niloticus [25]. Pseudomonas is well recognized and wide temperature range specific spoilage organism in fish stored under aerobic conditions [26]. Results from this study agree with previous report [3]. Pseudomonas is the specific spoilage bacteria of iced fresh fish in tropical waters [1]. It is known that Pseudomonas dominates at low temperatures because they exhibit a relatively lower generation time under aerobic 


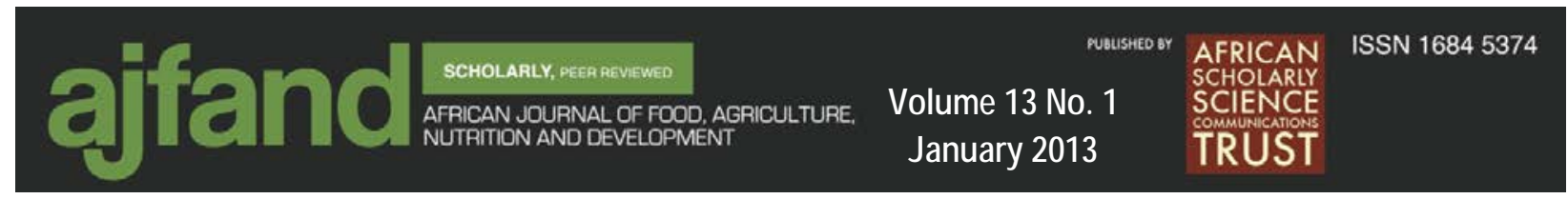

iced storage [27]. High populations of Micrococcus bacteria in this study also agree with earlier findings which indicate that gram positive bacteria micro flora such as Micrococcus dominates on fish from tropical waters [23].

Post-mortem $\mathrm{pH}$ varies considerably and $\mathrm{pH}$ has been used as a quick freshness indicator because muscle $\mathrm{pH}$ for live fish is generally neutral and increases as deterioration in quality of the fish progresses [28]. Decreasing $\mathrm{pH}$ values with storage time in ice reported for this study have been previously reported [29]. This is well supported by the observed slow growth of bacteria until sensory rejection. It has been suggested that tropical fish species reach a very low $\mathrm{pH}$ explaining why they have a longer shelflife [1]. Increased $\mathrm{pH}$ values after sensory rejection were also previously reported implicating accumulation of alkaline compounds as well as volatile bases produced by autolytic activities and metabolism of spoilage bacteria [28]. Thus, the increase in $\mathrm{pH}$ after day 16 could be associated with the state of rapid spoilage of the fish. The important link between ice storage and $\mathrm{pH}$ is that at low temperature, bacterial growth is inhibited from producing more volatile bases (raising $\mathrm{pH}$ ) which favours more microbial activity.

\section{CONCLUSIONS}

Lake Malawi Tilapia can remain safe for consumption up to 16 days after which the fish are sensorily rejected and bacterial load reaches unacceptable levels. It is also concluded that though fish may be safe to eat after 16 days since safety is generally related to presence of pathogenic bacteria, it would be unpalatable since organoleptic characteristics have changed. The importance of ice in reducing spoilage of fresh fish has also been demonstrated. This study, therefore, recommends encouraging use of ice by local fresh fish traders and processors. Since shelflife of fresh fish is influenced by multiple factors such as size of fish, type of ice and geographical location, there is a need to undertake similar work to test these factors. The need to determine shelflife of Lake Malawi Tilapia at other storage conditions other than chilling such as ambient storage is important because most local traders in Malawi display their fresh fish at open space without any form of preservation. It is also recommended that other objective methods for assessing freshness and quality of fresh fish such as chemical tests should be used to further validate these findings.

\section{ACKNOWLEDGEMENTS}

The authors sincerely thank the Regional Universities Forum for Capacity Building in Agriculture (RUFORUM) for funding this work; the Department of Aquaculture and Fisheries Science at Bunda College of Agriculture, for accommodating this study at their premises; Mr Elton Nyali and the laboratory team. Mr Placid Mpeketula and $\mathrm{Mr}$ Johannes Murowa from the Biology Department at Chancellor College helped with the microbiological work. We also sincerely thank Ms Guðný Jóhannsdóttir from the University of Akureyri in Iceland, for guiding in the shelflife computation. 
Table 1: Quality Index Method (QIM) Scheme developed for the assessment of whole fresh Lake Malawi Tilapia (chambo) fish stored in ice

\begin{tabular}{|c|c|c|c|}
\hline Quality parameter & & Description & Scores \\
\hline \multirow{4}{*}{ Appearance } & Skin & Shiny grey & 0 \\
\hline & & Grey, not shiny & 1 \\
\hline & Scale & Firm & 0 \\
\hline & & Loose & 1 \\
\hline \multirow{4}{*}{ Eyes } & Cornea & Very clear (glass-like) & 0 \\
\hline & & Cloudy & 1 \\
\hline & & Milky & 2 \\
\hline & & Opaque pupil & 3 \\
\hline \multirow[t]{11}{*}{ Gills } & Colour & Bright red & 0 \\
\hline & & Pale red & 1 \\
\hline & & Dull red & 2 \\
\hline & & Brown & 3 \\
\hline & Smell & Fresh, cut grass, aquatic weed & 0 \\
\hline & & Neutral & 1 \\
\hline & & Musty & 2 \\
\hline & Mucus & Clear & 0 \\
\hline & & Cloudy & 1 \\
\hline & & Milky & 2 \\
\hline & & Brown-reddish & 3 \\
\hline \multirow[t]{5}{*}{ Texture } & Backside & Firm \& elastic (in-rigor) & 0 \\
\hline & & Soft & 1 \\
\hline & & Very soft/ depression when pressed & 2 \\
\hline & Belly & Firm & 0 \\
\hline & & Soft & 1 \\
\hline Quality Index (QI) & & & $0-16$ \\
\hline
\end{tabular}

Table 2: Correlation between storage time in ice and freshness scores (QI) for Lake Malawi Tilapia (chambo) fish

\begin{tabular}{l|lrr}
\hline & \multicolumn{3}{|c}{ Days in ice Quality Index (QI) } \\
\hline Days in ice & Pearson Correlation & 1 & $.977(* *)$ \\
& Sig. (2-tailed) & & .000 \\
& N & 10 & 10 \\
\hline Quality Index (QI) & Pearson Correlation & $.977(* *)$ & 1 \\
& Sig. (2-tailed) & .000 & 10 \\
\hline$* *$ Correlation is significant at the 0.01 level (2-tailed)
\end{tabular}


Table 3: Mean population densities (TVC) of bacteria isolated from whole fresh Lake Malawi Tilapia (chambo) fish during storage in ice for 21 days

\begin{tabular}{|c|c|c|c|c|c|c|c|}
\hline \multirow[t]{2}{*}{ Fish part } & \multicolumn{7}{|c|}{ Days in ice } \\
\hline & 1 & 3 & 6 & 12 & 15 & 18 & 21 \\
\hline Skin surface $\left(\log \mathrm{cfu} / \mathrm{cm}^{2}\right)$ & $4.4 \times 10^{3}$ & $8.6 \times 10^{3}$ & $1.2 \times 10^{4}$ & $1.7 \times 10^{4}$ & $2.8 \times 10^{4}$ & $3.9 \times 10^{4}$ & $5.6 \times 10^{4}$ \\
\hline Mean SD & $2.2 \times 10^{2}$ & $7.7 \times 10^{2}$ & $1.0 \times 10^{3}$ & $1.5 \times 10^{3}$ & $3.3 \times 10^{3}$ & $1.1 \times 10^{3}$ & $3.0 \times 10^{3}$ \\
\hline Muscle (log cfu/g) & $1.1 \times 10^{2}$ & $3.8 \times 10^{3}$ & $9.8 \times 10^{3}$ & $2.7 \times 10^{4}$ & $1.8 \times 10^{5}$ & $2.5 \times 10^{5}$ & $6.2 \times 10^{5}$ \\
\hline Mean SD & $2.6 \times 10^{1}$ & $5.2 \times 10^{2}$ & $3.0 \times 10^{2}$ & $3.0 \times 10^{3}$ & $2.1 \times 10^{5}$ & $3.1 \times 10^{4}$ & $4.4 \times 10^{4}$ \\
\hline Gills (log cfu/g) & $1.2 \times 10^{5}$ & $1.9 \times 10^{5}$ & $2.1 \times 10^{5}$ & $2.6 \times 10^{5}$ & $4.0 \times 10^{5}$ & $3.6 \times 10^{5}$ & $2.5 \times 10^{5}$ \\
\hline Mean SD & $1.0 \times 10^{5}$ & $1.1 \times 10^{4}$ & $2.6 \times 10^{3}$ & $3.610^{3}$ & $5.0 \times 10^{3}$ & $5.4 \times 10^{4}$ & $7.6 \times 10^{3}$ \\
\hline Kidney (log cfu/g) & $9.1 \times 10^{3}$ & $7.3 \times 10^{4}$ & $1.9 \times 10^{4}$ & $1.2 \times 10^{4}$ & $7.2 \times 10^{3}$ & $3.8 \times 10^{3}$ & $2.5 \times 10^{4}$ \\
\hline Mean SD & $6.7 \times 10^{2}$ & $9.2 \times 10^{4}$ & $2.0 \times 10^{3}$ & $1.7 \times 10^{3}$ & $1.0 \times 10^{3}$ & $2.4 \times 10^{3}$ & $1.2 \times 10^{4}$ \\
\hline Intestines (log cfu/g) & $4.0 \times 10^{3}$ & $1.4 \times 10^{6}$ & $1.7 \times 10^{6}$ & $7.7 \times 10^{6}$ & $8.0 \times 10^{7}$ & $8.4 \times 10^{7}$ & $9.6 \times 10^{7}$ \\
\hline Mean SD & $6.4 \times 10^{2}$ & $1.2 \times 10^{5}$ & $1.5 \times 10^{6}$ & $8.5 \times 10^{5}$ & $5.2 \times 10^{6}$ & $1.1 \times 10^{7}$ & $1.5 \times 10^{6}$ \\
\hline TVC (log cfu/g/cm²) & $2.9 \times 10^{4}$ & $3.5 \times 10^{5}$ & $3.9 \times 10^{5}$ & $1.6 \times 10^{6}$ & $1.6 \times 10^{7}$ & $1.6 \times 10^{7}$ & $1.9 \times 10^{7}$ \\
\hline Mean SD & $6.4 \times 10^{4}$ & $5.8 \times 10^{5}$ & $9.0 \times 10^{5}$ & $3.1 \times 10^{6}$ & $3.3 \times 10^{7}$ & $3.4 \times 10^{7}$ & $3.9 \times 10^{7}$ \\
\hline
\end{tabular}

Table 4: Pearson Correlation coefficients ( $r$ ) between sensory quality index (QI) scores and bacterial total viable counts (TVC) for Lake Malawi Tilapia (chambo) fish stored in ice

\begin{tabular}{|c|c|c|}
\hline & QI & TVC \\
\hline QI & 1 & \\
\hline TVC & $.903^{*}$ & 1 \\
\hline
\end{tabular}




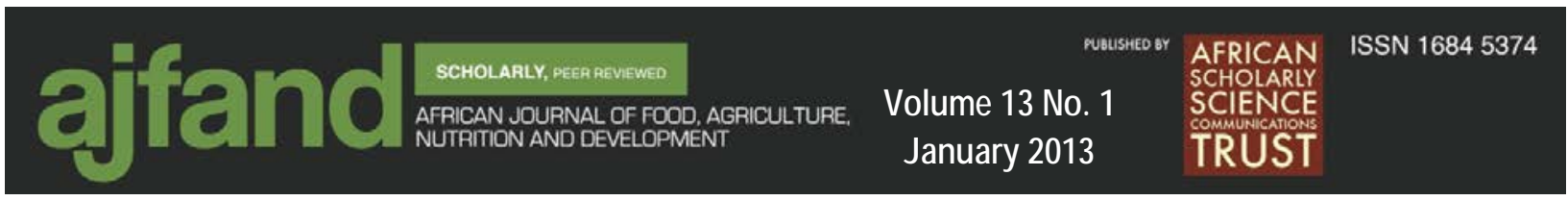

Table 5: Bacteria isolates from different parts of Lake Malawi Tilapia (chambo) fish stored in ice for 21 days ( $+=$ present, - = absent)

\begin{tabular}{|c|c|c|c|c|c|c|c|c|c|}
\hline \multirow[b]{2}{*}{ Fish Part } & \multirow[b]{2}{*}{ Bacteria isolate type } & \multicolumn{8}{|c|}{ Days stored in ice } \\
\hline & & 0 & 3 & 6 & 9 & 12 & 15 & 18 & 21 \\
\hline \multirow[t]{7}{*}{ Skin surface } & Acinetobacter sp & + & - & - & + & + & + & + & + \\
\hline & Corynebacterium sp & + & - & - & - & - & - & - & - \\
\hline & Flavobacterium sp & - & - & + & + & + & + & + & + \\
\hline & Lactobacillus sp & + & - & - & - & - & - & - & - \\
\hline & Micrococcus sp & + & + & + & + & + & + & + & + \\
\hline & Pseudomonas sp & + & + & + & + & + & + & + & + \\
\hline & Shigella sp & + & + & + & + & + & + & + & + \\
\hline \multirow[t]{3}{*}{ Muscle } & Flavobacterium $s p$ & - & - & + & + & + & + & + & + \\
\hline & Micrococcus sp & + & + & + & + & + & + & + & + \\
\hline & Pseudomonas sp & - & + & + & + & + & + & + & + \\
\hline \multirow[t]{8}{*}{ Gills } & Bacillus sp & + & + & + & - & - & - & - & - \\
\hline & Escherichia coli & - & + & + & - & - & - & - & - \\
\hline & Flavobacterium sp & - & - & + & + & + & + & + & + \\
\hline & Micrococcus sp & + & + & + & + & + & + & + & + \\
\hline & Pseudomonas sp & - & + & + & + & + & + & + & + \\
\hline & Vibrio sp & - & - & + & + & + & + & + & + \\
\hline & Shigella sp & + & + & + & + & + & + & + & + \\
\hline & Salmonella sp & + & + & + & + & + & + & + & + \\
\hline \multirow[t]{9}{*}{ Intestines } & Bacillus sp & + & + & + & + & - & - & - & - \\
\hline & Escherichia coli & + & + & + & + & + & + & + & + \\
\hline & Flavobacterium $s p$ & + & + & + & - & - & - & - & - \\
\hline & Micrococcus sp & + & + & + & + & + & + & + & + \\
\hline & Pseudomonas sp & - & - & + & + & + & + & + & + \\
\hline & Vibrio sp & - & + & + & + & + & + & + & + \\
\hline & Staphylococcus sp & + & - & - & - & - & - & - & - \\
\hline & Shigella sp & + & + & + & + & + & + & + & + \\
\hline & Salmonella sp & + & + & + & + & + & + & + & + \\
\hline \multirow[t]{3}{*}{ Kidney } & Escherichia coli & - & + & + & + & - & - & - & - \\
\hline & Micrococcus sp & + & + & + & + & + & + & + & + \\
\hline & Pseudomonas sp & - & + & + & + & + & + & + & + \\
\hline
\end{tabular}




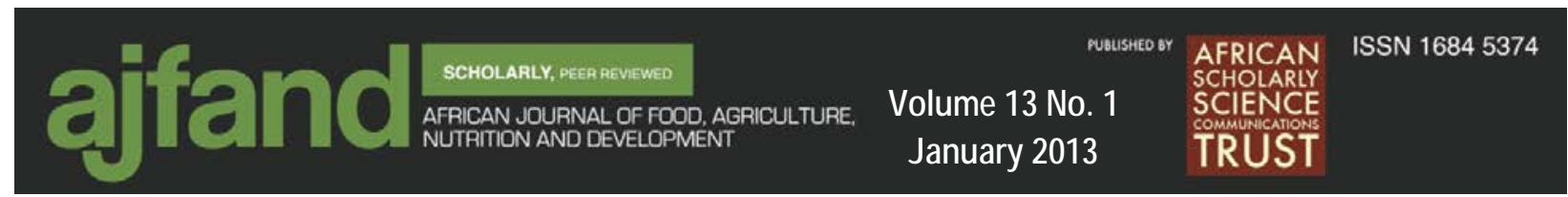

\section{REFERENCES}

1. Huss HH Quality and quality changes in fresh fish. FAO Fisheries Technical Paper. No. 348. FAO, Rome, 1995.

2. Adams MR and MO Moss Food Microbiology ( ${ }^{\text {rd }}$ Edition). The Royal Society of Chemistry, Cambridge, UK; 2008; 179.

3. Guo QY, Wang XC, Yang XS, Xu Z, Gu M and XY Li Freshness changes and shelflife prediction of cultured tilapia (Oreochromis niloticus) during chilled storage. Intelligent Computation Technology and Automation (ICICTA), International Conference 2011; 86-92.

4. Banda M, Jamu D, Njaya F, Makuwila M and A Maluwa The Chambo restoration strategic plan: Proceedings of the national workshop held on 13-16 May 2003 at Boadzulu Lakeshore Resort, Mangochi (Malawi). In: WorldFish Center Conference Proceedings (Malaysia). WorldFish Center: Penang, Malaysia 2005.

5. Weyl OLF, Kazembe J, Booth AJ and DS Mandere An assessment of the light attraction fishery in southern Lake Malawi. African Journal of Aquatic Science 2004; 29: 1-11.

6. Kapute F, Kaunda E, Banda M, and S Morioka Maturity, age and growth of Oreochromis karongae (Teleostei: Cichlidae) in Lakes Malawi and Malombe, Malawi. African Journal of Aquatic Science 2008; 33: 69-76.

7. Ghaly AE, Dave D, Budge S and MS Brooks Fish spoilage mechanisms and preservation techniques: review. American Journal of Applied Sciences 2010; 7: 859-877.

8. Huidobro A, Pastor A, Lopez-Caballero ME and M Tejada Washing effect on the quality index method (QIM) developed for raw gilthead sea bream (Sparus aurata). European Food Research and Technology 2001; 212: 408412.

9. Baixas-Nogueras S, Bover-Cid S, Veciana-Nogués T, Nunes ML and MC Vidal-Carou Development of Quality Index Method to Evaluate Freshness in Mediterranean Hake (Merluccius merluccius). Journal of Food Science 2003; 68: $1067-1071$.

10. Masette $\mathbf{M}$ and $\mathbf{T}$ Kasiga The effect of size and holding temperatures on rigor mortis phenomenon in Nile Tilapia (Oreochromis niloticus). In: FAO Workshop on Fish Technology, utilization and quality assurance. FAO Fisheries Report No. 819. Bagamoyo, Tanzania 2005, 17-25. 
11. Martinsdóttir E, Sveinsdóttir K, Luten J, Schelvis-Smit R and G Hyldig Reference Manual for the Fish sector: Sensory Evaluation of Fish freshness. QIM Euro Fish. The Netherlands 2001.

12. Okoro CC, Aboaba OO and OJ Babajide Quality Assessment of a Nigerian Marine Fish, Mullet (Liza falcipinnis) under different Storage Conditions. New York Science Journal 2010; 3: 21-28.

13. Sveinsdottir K, Hyldig G, Martinsdottir E, Jorgensen B, and $\mathbf{K}$ Kristbergsson Quality Index Method (QIM) scheme developed for farmed Atlantic salmon (Salmo salar). Food Quality and Preference 2003; 14: 237245.

14. Mai NTT, Martinsdóttir E, Sveinsdóttir K, Ólafsdóttir G and S Arason Application of Quality Index Method, Texture Measurements and Electronic Nose to Assess the Freshness of Atlantic Herring (Clupea harengus) stored in ice. World Academy of Science, Engineering and Technology 2009; 57: 283289.

15. Adoga IJ, Joseph E and OF Samuel Shelflife of Tilapia (Oreochromis niloticus) in Ice and Ambient Temperature. Researcher 2010; 2: 39-44.

16. Gram L, Oundo J, and $\mathbf{J}$ Bon Shelflife of Nile perch (Lates niloticus) dependent on storage temperature and initial bacterial load. Journal of Tropical Science 1989; 29: 221-236.

17. Okeyo GO, Lokuruka MNI and JW Matofari Nutritional composition and shelflife of the Lake Victoria Nile perch (Lates niloticus) stored in ice. African Journal of Food, Agriculture, Nutrition and Development 2009; 9: 901-919.

18. Zhong X, Xian-Shi $\mathbf{Y}$ and $\mathbf{X}$ Lin-Lin. Studies on the Microbiological Quality Change and Storage Time of Tilapia at Different Cold Storage Temperatures. Journal of Ocean University of Qingdao, 2005-04.

19. Surendran PK, Jose Joseph AV, Shenoy PA, Perigreen K, Mahadeva I and K Gopakumar Studies of spoilage of commercially important tropical fishes under iced storage. Fisheries Research 1989; 7: 1-9.

20. ICMSF (International Commission on Microbiological Specifications for Foods) Microorganisms in Foods 2, Sampling for Microbiological Analysis. Principles and Specific Applications, $2^{\text {nd }}$ edition. Oxford: Blackwell Science, 1986.

21. Koutsoumanis $\mathbf{K}$ Predictive modeling of the shelflife of fish under non isothermal conditions. Applied Environmental Microbiology 2001; 67: 18211829. 
22. Austin B The Bacterial Micro flora of Fish. The Scientific World Journal 2002; 2: 558-572.

23. Shewan JM The Microbiology of Sea-Water Fish. In: G Borgstrom (Ed), Fish as Food. Academic Press, Florida, USA: 1962, 487-560.

24. Shawyer M and AF Medina Pizzali The use of ice on small fishing vessels. FAO Fisheries Technical Paper No. 436. FAO, Rome, 2003, 108.

25. Azza MA, Khattab YAE and AME Shalaby Micrococcus luteus and Pseudomonas species as probiotics for promoting the growth performance and health of Nile tilapia, Oreochromis niloticus. Fish and Shellfish Immunology 2009; 27: 175-180.

26. Xu Y, Lin H, Sui J and L Cao Effects of specific egg yolk antibody (IgY) on the quality and shelflife of refrigerated Paralichthys olivaceus. Journal of the Science of Food and Agriculture 2012; 92: 1267-1272.

27. Devaraju AN and TMR Setty Comparative study of fish bacteria from tropical and cold/temperate marine waters. In: A Reilly (Ed). Spoilage of tropical fish and product development. Rome, Italy: FAO Fisheries Report No. 317 Supplement 198: 97-107.

28. Liu S, Fan W, Zhong S, Ma C, Li P, Zhou K, Peng Z and M Zhu Quality evaluation of tray-packed tilapia fillets stored at $0^{\circ} \mathrm{C}$ based on sensory, microbiological, biochemical and physical attributes. African Journal of Biotechnology 2010; 9: 692-701.

29. Obemeata O, Nnenna FP and $\mathbf{N}$ Christopher Microbiological assessment of stored Tilapia guineensis. African Journal of Food Science 2011; 5: 242-247. 